\begin{tabular}{|l|l|l||}
\hline \multicolumn{2}{|c|}{ PublisherInfo } \\
\hline \hline PublisherName & $:$ & BioMed Central \\
\hline \hline PublisherLocation & $:$ & London \\
\hline \hline PublisherImprintName & $:$ & BioMed Central \\
\hline \hline
\end{tabular}

\title{
Are SNPs useful?
}

\begin{tabular}{|l|l|l||}
\hline \multicolumn{2}{|c|}{ ArticleInfo } \\
\hline \hline ArticleID & $:$ & 4042 \\
\hline \hline ArticleDOI & $:$ & $10.1186 /$ gb-spotlight-20010405-02 \\
\hline \hline ArticleCitationID & $:$ & spotlight-20010405-02 \\
\hline \hline ArticleSequenceNumber & $:$ & 113 \\
\hline \hline ArticleCategory & $:$ & Research news \\
\hline ArticleFirstPage & $:$ & 1 \\
\hline \hline ArticleLastPage & $:$ & 2 \\
\hline \hline & $:$ & RegistrationDate : 2001-04-05 \\
ArticleHistory & $:$ & OnlineDate $:$ 2001-04-05 \\
\hline \hline ArticleCopyright & $:$ & BioMed Central Ltd2001 \\
\hline \hline ArticleGrants & $:$ & \\
\hline \hline ArticleContext & $:$ & 130592211 \\
\hline \hline
\end{tabular}




\section{Jonathan B Weitzman}

Email: jonathanweitzman@hotmail.com

In the April Nature Genetics, Marth et al. ask the question how useful are the single-nucleotide polymorphisms (SNPs) available in the public-access databases (Nature Genetics 2001, 27:371-372). The public database dbSNP currently holds over 2.8 million SNPs, but as few as $15 \%$ have been proven to be genuinely polymorphic. Marth et al. performed two pilot studies to test the genetic utility of candidate SNPs. They analysed over 1200 candidate SNPs and tested their frequency in three ethnic groups (Caucasian, Chinese and African) using a pooled DNA sequencing approach. Almost $80 \%$ of the candidates were found to be polymorphic. And about half of the SNPs were common within the three populations (with a minor allele frequency of $>20 \%$ ). Hence SNPs within the dbSNP database can be used with a high degree of confidence that they will be informative.

\section{References}

1. Nature Genetics, [http://genetics.nature.com]

2. dbSNP, [http://www.ncbi.nlm.nih.gov/SNP]

3. Comparative analysis of human DNA variations by fluorescence-based sequencing of PCR products.

This PDF file was created after publication. 